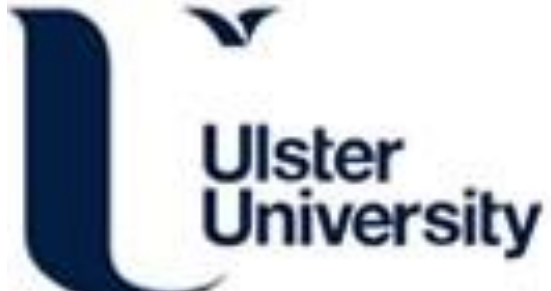

Characterizing flood risk perception in urban communities of Pakistan

Rana, I. A., Jamshed, A., Younas, Z. I., \& Bhatti, S. S. (2020). Characterizing flood risk perception in urban communities of Pakistan. International Journal of Disaster Risk Reduction, 46, [101624].

https://doi.org/10.1016/j.ijdrr.2020.101624

Link to publication record in Ulster University Research Portal

\section{Published in:}

International Journal of Disaster Risk Reduction

Publication Status:

Published (in print/issue): 01/06/2020

DOI:

10.1016/j.jjdrr.2020.101624

\section{Document Version}

Author Accepted version

\section{General rights}

Copyright for the publications made accessible via Ulster University's Research Portal is retained by the author(s) and / or other copyright owners and it is a condition of accessing these publications that users recognise and abide by the legal requirements associated with these rights.

\section{Take down policy}

The Research Portal is Ulster University's institutional repository that provides access to Ulster's research outputs. Every effort has been made to ensure that content in the Research Portal does not infringe any person's rights, or applicable UK laws. If you discover content in the Research Portal that you believe breaches copyright or violates any law, please contact pure-support@ulster.ac.uk. 


\title{
INTERNATIONAL JOURNAL OF DISASTER RISK REDUCTION
}

\author{
CHARACTERIZING FLOOD RISK PERCEPTION IN URBAN COMMUNITIES OF PAKISTAN \\ Irfan Ahmad Rana ${ }^{\text {a }}$; Ali Jamshed ${ }^{\text {; }}$; Zahid Irshad Younas ${ }^{c}$; and Saad Saleem Bhatti ${ }^{d}$ \\ a Department of Urban and Regional Planning, School of Civil and Environmental Engineering (SCEE), \\ National University of Sciences and Technology (NUST), Islamabad, Pakista \\ ${ }^{\mathrm{b}}$ Institute of Spatial and Regional Planning (IREUS), University of Stuttgart, Germany \\ c NUST Business School (NBS), National University of Sciences and Technology (NUST), Islamabad, \\ Pakistan \\ ${ }^{\mathrm{d}}$ School of Geography and Environmental Sciences, Ulster University, Coleraine, UK
}

\begin{abstract}
Rapid urbanization and climate change have increased flood risk in urban settings. Risk perception is a vital constituent of flood risk management and risk communication. It has become important to understand risk perception so that appropriate disaster risk reduction strategies can be initiated. Socioeconomic factors influencing risk perception have a direct impact on potential adaptive capacities and disaster preparedness. This study gives an insight into psychosocial aspect of multifaceted risk in flood prone urban communities of Punjab, Pakistan. Three urban communities at high flood risk were selected from urban centres of different population size. A sample of 210 was collected using household surveys. Flood risk perception index was constructed using relevant indicators, and classified into high and low perceived risk. Logistic regression model was used to identify determinants of flood risk perception. The results show that past experiences and hazard proximity significantly influence risk perception. The determinants of risk perception also varied among the communities, depicting spatial variation. Findings of this study can help understanding flood risk perception and its determinants, in order to design proper risk communication strategies and flood risk management plans. In addition, this study can also support understanding multidimensional flood risk and its spatial dynamics from a social science perspective.
\end{abstract}

Keywords: Determinants; Flood management; Psychosocial; Risk assessment; Socioeconomic

\section{Introduction}

Risk perception has become an important research agenda in disaster risk science. It predicts the willingness of exposed communities to undertake precautionary measures against external threats [[1], [2], [3]]. It is also seen as a factor predicting protective actions against natural hazards [4]. With higher risk perception, it is expected that the communities will also increase their capacities by undertaking climate change adaptation and disaster preparedness initiatives. Risk perception shows acceptability of risk and to some extent, predicts the community responses which subsequently helps designing appropriate public education programs and risk communication strategies [5]. Risk perception is also considered as an important component of social vulnerability assessment and community resilience [1]. Consequently, risk perception has become an important constituent of disaster risk reduction (DRR) and climate change adaptation.

Flood is the most common and deadliest natural hazard in the world $[6,7]$. The frequency and intensity of flood events, especially in the Global South, have increased over the last few decades. There were an estimated 539,811 deaths, 361,974 injuries and 2.8 billion people affected by floods during 1980 and 2009 [6]. Between 1980 and 2016, total direct damages exceeded 1.6 trillion USD [8]. Asia is the worst affected region in the world, accounting for more than $50 \%$ of fatalities [6]. It is projected that climate change, extreme rainfall events and sea level rise would increase the flood risk $[9,10]$. Another reason, and arguably the bigger driver for the rise in flood-related damages, is the increase in population and infrastructure development in floodplains - urban areas are becoming hotspots of disaster risks [11,12]. Sustainable Development Goals (SDG) and UN- 
HABITAT's New Urban Agenda calls for making cities safe, resilient and inclusive [13,14]. Both the "inclusive" and "resilient" aspects can be achieved by understanding the risk perception (and its determinants) of urban inhabitants.

Pakistan is a developing country in South Asia with a population of almost 207 million [78]. The average GDP growth of the country is 5.5\% and ranked 147 on the Human Development Index (HDI) [15]. Its socioeconomic and physical development are focused on large urban areas resulting in disparity in small cities and rural areas [16]. With several basic issues such as health, education, poverty, housing, population growth and economic instability at the centre stage of government priorities, there is little room for disaster management. As a result, disaster management is carried out on an ad-hoc basis, with a top-down and reactive approach [17].

It is believed that climate change could possibly increase the frequency and severity of floods and therefore, it has become essential to assess how communities respond to these events $[10,18]$. Risk perception may vary spatially depending on exposure, socioeconomic conditions, cultural and religious backgrounds. Literature calls for more empirical testing in various settings for potential new insights and establishment of "well-grounded" theory [19]. In developing countries, especially Pakistan, limited studies have been conducted to examine risk perception and its determinants. Hence, it is imperative to study risk perception and its determinants that can influence communities. The objectives of this study are to: (1) examine the levels of risk perception; (2) determine the socioeconomic factors influencing risk perception; and (3) understand the spatial variability of risk perception in three flood-prone communities (Dhok Ratta, Rawalpindi; Hajipura, Sialkot; and Khangarh, Muzaffargarh) in the province of Punjab, Pakistan. The next section of the paper presents an extended review of literature on risk perception, followed by the description of data and methods employed in this study. The findings on flood hazard exposure and risk perception in the selected communities are discussed in the results section, whereas important implications for policy makers and other stakeholders are presented at the end of this paper.

\section{Revisiting risk perception}

The term risk has become an important parameter in disaster risk and climate change science. Actual risk is measured by experts based on hazard, exposure, sensitivities and capacities of communities $[10,12]$. On the contrary, the perceived risk is based on exposure, past experiences, community/individual understanding and cognitive thinking (the way a potential victim understands the risk) or socio-political factors [20]. Actual risk is often based on statistical probability of hazard occurrence, while perceived risk reflects perceived likelihood [4]. Literature argues that there is an association between actual and perceived risk $[17,21,22]$. Both types of risk assessments are integral for effective DRR and formulation of disaster risk management plans, especially risk communication strategies $[1,10,21,23]$.

\subsection{Risk perception}

Risk perception is intensively studied in social sciences and psychology fields. The terminology is widely used to measure psychological influence on decision making and consequent actions. Risk perception has emerged as a standard scientific method to assess public acceptance and their reactions/adjustments regarding a potential hazard. Generally, it can be defined as "people's judgements about events, situations or activities that could lead to negative consequences" [24], or "people's judgements against potential hazard and appropriate behavioural responses" [25]. Researchers agree that human behaviours, decisions and actions are driven by their perceptions $[24,26]$. A pioneer study, which instigated risk perception studies, was done by Gilbert F. White on flood adjustments in the United States [27]. Early studies concluded that hazard perception/awareness and its determinants can influence precautionary measures against hazards $[28,29]$. Different groups involved in flood risk management would perceive risk differently, and 
influence their future risks [30]. Consequently, local, national and international agencies are increasingly relying on it to understand the acceptance or rejection of new policies or technologies [31]. In the fields of disaster risk science and climate change adaptation, risk perception is now being studied to increase social acceptability and awareness for effective DRR and climate change mitigation [1,32]. Risk perception is a key component to evaluate public strategies as well as adaptive capacity of communities to a certain extent [32]. The term hazard adjustment is also sometimes alternatively used from a hazard mitigation perspective, mostly when a person modifies their behaviour against a particular hazard [33].

Different frameworks, models and schools of thought have tried to explain the conceptual understanding of risk perception (see [[1], [20], [31], [34]]). Broadly, "rationalism" and "constructivism" approaches have been used to interpret evidences and develop theories to better understand the multifaceted concept of risk perception [[1], [35]]. The rationalism approach considers risk perception as an individual's mental construct for evaluating benefits and costs regarding any decision. Under this approach, the theory of prospect/heuristics and psychometric paradigm are well-established. Heuristics theory demonstrates how different individuals make decisions under uncertain conditions keeping in view the potential gains and losses [34].

Psychometric paradigm, on the other hand, focuses on an individual's cognitive variables that may affect risk perception [1]. Well-documented theories of bounded rationality and protection motivation can also be categorized under this approach. In terms of flood, empirical studies have been conducted to link psychometric paradigm, heuristics theory and risk perception [32,[36], [37], [38], [39], [40], [41]]. However, rationalism approach is often criticized for using subjective methods to assess mental construct, which might not reflect a clear picture [20].

On the other hand, constructivism approach views risk perception from a sociological perspective. This approach includes well-known theories such as social construction/amplification of risk and cultural theory. The social construction theory argues that risk perception is influenced by sociopolitical factors [42]. Similarly, cultural theory emphasizes that risk perception is dependent on social structures, organizations and cultures $[20,24]$. Empirical studies on linking cultural theory with flood risk perception have been conducted [[43], [44], [45]]. However, the constructivism approach has also been criticized, as it fails to provide empirical evidences through qualitative methods and weak methodologies [31]. Although both the approaches are distinct, each has significantly helped in refining the theory and conceptual understanding of risk perception [20].

\subsection{Flood risk perception}

Risk perception is now widely used in disaster literature to understand community reactions and responses to disaster risk - it is also a crucial factor in developing effective flood risk management strategies [1]. Assessing the flood risk perception is critical as it is positively and significantly correlated with disaster preparedness and climate change adaptation [46]. However, governments and concerned departments often overlook flood risk perception in favour of structural flood mitigation measures [1]. High risk perception reflects higher chances of community participation in disaster risk initiatives [2], as well as in believing and acting on flood early warnings [47], opting for insurance [36,43], undertaking adaptation measures and protective/preparedness actions $[1,23,46]$, adopting mitigation and prevention strategies [18,48], enhancing social capital [49], and compliance with emergency protocols [21]. Considering these implications, flood risk perception has now become integral to reducing flood risk and adapting to climate change.

Empirical research has been conducted to explore flood risk perception and its characteristics, but still warrants further investigation [1]. Such studies on flood risk perception have been conducted in Austria [49], Australia [18,23,43], Belgium [50], Greece [5], Italy [46], Ireland [51], Netherlands [36], Romania [52], Switzerland [22], Taiwan [32], Uganda [4], and USA [21,26,53]. Although some 
research has been done in terms of risk perception assessment in Pakistan, it generally focused on earthquakes [2,54], droughts [55] and landslides [56]. The risk perception-related research in context of floods has concentrated mainly on the farmers and rural sector of the country [48,[57], [58], [59], [60], [61]]. In Pakistan, risk perception and its determinants have been addressed only in a handful of studies and that too in the rural context, this study aims at understanding the risk perception and disaster risk in urban areas.

\subsection{Determinants of flood risk perception}

Risk perception varies from individual to individual and community to community, and is highly dependent on socioeconomic factors. Burton and Kates (1964) classified explanatory factors influencing flood risk perception as the relation of hazard to the dominant resource use, the frequency of occurrence of floods, and variations in degree of personal experience [29]. Wachinger et al. (2013) classified it into various categories like scientific risk (likelihood), personal (age, gender), contextual (education, experience) and informational (media, risk communication) [62]. Aerts et al. (2018) categorized the determinants of flood risk as social (age, literacy), economic (income, equity), geographic (scale and distance to flood zone), culture (heritage and language) and information (media and data availability) [10], whereas Lechowska (2018) classified them by their nature (cognitive, demographical, geophysical etc.) and influence (worry, preparedness, awareness) [63]. These factors change the acceptable risk and adaptation strategies among individuals or communities, even if the actual hazard levels or facts remain the same [4]. Thus, it is imperative to study the determinants of flood risk perception, so that it can help developing flood risk management strategies. Although numerous factors influence flood risk perception, the following are identified and selected as being relevant to assess the "socioeconomic" variables after an extensive literature review.

\subsubsection{Age and gender}

Variation in age influences cognitive thinking, and consequently perceived risk. It is also sometimes correlated with past experiences, sense of place and flood preparedness [46]. It is observed that older people perceive risk higher than the young [50]. Age was found to significantly affect or correlate with flood risk perception in several research studies $[5,21,46,49,50]$, whereas some studies suggest the opposite $[51,57]$. In the context of gender, literature argues that risk perception varies among the groups [21,26,50]. Females tend to perceive higher flood risk than men [23]. However, some studies also suggest that there are no gendered influences on flood risk perception $[4,5,36,[49],[50],[51], 53,60]$.

\subsubsection{Income and occupation}

Some studies suggest that the type of occupation and income influences the flood risk perception $[4,21,26,49,53]$, however, other researchers could not find any such relationship $[32,36,51,60]$.

\subsubsection{Education and knowledge}

Communities or individuals with little or no formal education have limited access to sources of information and understanding in making decisions. Less informed communities are generally at more risk from hazards than they realize. Many research studies have found that education and access to knowledge influences risk perception $[21,36,60]$. People who are less educated usually perceive low risk. However, in some cases, it has also been reported that education does not influence flood risk perception at all [29,32,51,53,57].

\subsubsection{Past experiences}

Households which have experienced floods are more ready to accept potential threats and may make better decisions. People who have experienced hazards in the past tend to perceive high flood risk [50], and thus undertake preventive strategies or hazard adjustments $[18,26]$. There exists a 
strong association $[5,26,29,36,49,60]$ or partial association $[32,50,53]$ between past experiences and flood risk perception.

\subsubsection{House ownership and its location}

Kellens et al. (2011) suggest that there is no link between flood risk perception and house ownership - this has been supported by other research studies as well $[53,57]$. However, some researchers found a strong relationship between house ownership and flood risk perception $[51,60]$. In the case of hazard proximity and location of the house, literature argues that they tend to influence flood risk perception. Kellens et al. (2011) also found that levels of risk perception vary according to location [50]. Another study suggests that the terrain and location of farmland significantly influence farmer's flood risk perception [4]. Evidence supports that hazard proximity can sometimes partially influence flood risk perception [26,46]. Distance from hazard source and elevation is also found to significantly affect flood risk perception $[36,49,51]$.

\section{Materials and methods}

Three urban areas of varying population sizes, based on their high flood risk classification by the National Disaster Management Authority (NDMA), Pakistan, were chosen for this study. A questionnaire was developed and household survey was conducted to collect the data for assessing the flood risk perception through an index-based approach. Thereafter, regression analyses were performed to identify the socioeconomic determinants of risk perception in the selected flood prone communities.

\subsection{Study area}

In Pakistan, floods account for almost $48 \%$ of all natural hazards [64]. Around 67 out of 156 districts in the country are declared as areas of 'very high' and 'high' flood risk [65]. The flood intensity and frequency have increased markedly in the last ten years [66] where the flood events caused loss of billions of dollars to the economy while seriously damaging the infrastructure services [67]. This rise is attributed primarily to the changing rainfall patterns and rapid melting of glaciers in the north due to climate change [68]. The flood event of 2010 was colossal and caught massive international attention [66]. Moreover, the 2010 and subsequent climate-related flood events also uncovered additional vulnerabilities and risks associated with socio-economic and physical conditions of the flood-prone communities.

This study was conducted in the Punjab province of Pakistan which houses more than half of the country's population. The province's urban and rural areas are highly prone to flood hazards as five major rivers pass through it. In order to study the risk perception of urban flood-prone communities, case study areas were selected in three stages: (1) the districts which were highly prone to flooding were shortlisted; (2) three cities of different population sizes (large, medium and small) were selected from within the districts shortlisted in stage 1; and (3) one urban union council ${ }^{1}$ (UC) prone to floods and which has experienced flood-related damages in the past was selected from within each city identified in stage 2. Considering these criteria, Rawalpindi, Sialkot and Muzaffargarh were selected as large, medium and small cities respectively, where further down, the household surveys were conducted in Dhok Ratta, Hajipura and Khangarh UCs within these cities.

Rawalpindi is the fourth largest urban centre of Pakistan (2.8 million population) and serves multiple functions [69]. It is located about $14 \mathrm{~km}$ south of the federal capital (Islamabad) and spans over an area of $60 \mathrm{sq} . \mathrm{km}$. Nullah Lai, a rainfed natural stream, passing right in the middle of the city is the primary source of floods. In the past 70 years, around 20 floods occurred where the flood events of 1981, 1988, 1997, 2001 and 2005 were massive and submerged almost half of the landmass of the

\footnotetext{
${ }^{1}$ Union council is the smallest administrative tier in Punjab Province (as of Punjab Local Government Ordinance, 2001).
} 
city. In the 2001 flood event alone, 74 people died, 400,000 were displaced and around 3500 houses were destroyed [70]. A flood prone UC named Dhok Ratta in Rawalpindi was selected as one of the areas to conduct this study (Fig. 1).

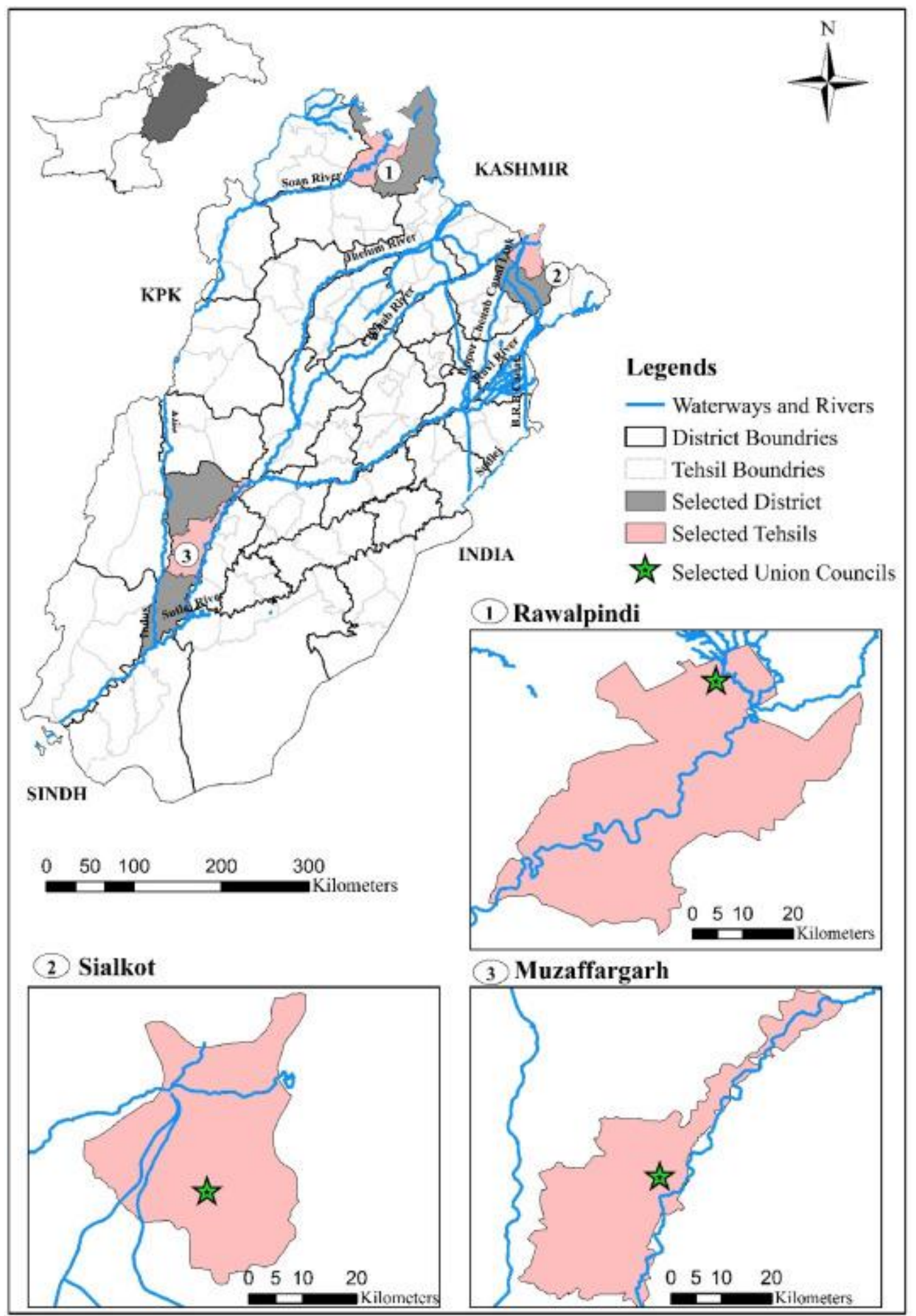

Fig. 1. Location of selected communities.

Source: Authors, 2019 
Sialkot is one of the oldest and an important industrial city of Pakistan accommodating around 0.55 million people [69]. It is located approximately $220 \mathrm{~km}$ to the south-east of the federal capital and its urban area spans 43 sq. $\mathrm{km}$. Water streams namely Nullah Aik and Nullah Degh are the main sources of flooding in the city. Monsoon rains together with industrial waste clogging the drains cause pluvial flooding. Flood event of 2014 was deadly which took 35 lives and destroyed more than 1800 houses [71]. A flood affected UC, Hajipura was selected to study the risk perception of people (Fig. 1).

Muzaffargarh is a small city having an urban population of around 0.2 million residing over an area of $35 \mathrm{sq} . \mathrm{km}$ [69]. It is located some $500 \mathrm{~km}$ south-west of Islamabad and is mainly characterized by agro-industrial function. Muzaffargarh was the worst affected by floods in the past due to its geographical location between two main rivers, Indus and Chenab. The city experienced extreme flooding in 2010 and large-scale floods in the following years. An urban UC - Khangarh City - which is at high flood risk was chosen for this study (Fig. 1).

\subsection{Sampling and data collection}

Cochran's method was used to identify the required number of samples [72]. According to the Punjab Development Statistics Report (2014), the three selected communities housed a total of 12,867 inhabitants [73]. With the confidence level of $95 \%$ and a precision value of 0.07 , the Cochran's sampling method gave a minimum number of 194 samples as being a suitable representative of the population. Using proportionate method, the required number was distributed among the three urban communities - a minimum of 64,69 , and 61 samples were thus required from Rawalpindi, Sialkot, and Muzaffargarh communities, respectively. The sample size was rounded off to the upper limit and 70 samples were collected from each community (a total of 210).

Pretesting in the field was done in early June, 2015 to streamline the household questionnaire. Thereafter, a full-fledged random survey was conducted during June-July, 2015 and total 210 valid and complete questionnaires were collected.

\subsection{Flood risk perception index}

Risk perception is generally qualitative in nature; however, indices have proved to be useful as one of the methods to quantify it. Indices in disaster risk science and climate change vulnerability are seen as a robust methodology to summarize and quantify complicated data into a simpler form [74]. Construction of an index requires data standardization to aggregate the datasets. However, weights are also used to standardize the responses for the computation of composite index [17].

Risk perception indicators were carefully chosen after rigorous literature review (Table 1). Some of the selected indicators such as perceived ability to cope, knowledge about emergency protocols and trust in government policies, although do not provide the 'direct measure of risk perception', do give the measure of the 'ability to cope with the risk' which indirectly relates to the overall perceived risk. Each indicator was mapped on a Likert scale of 1-5. Each scale was given weight on how much it increases risk perception ( $1=$ Very high, $0.8=$ High, $0.6=$ Moderate, $0.4=$ Low and $0.2=$ Very low). These weights/scores were added to come up with a composite index $(\mathrm{Cl})$ value for each household (Eq. (1)). Flood Risk perception index was thus formulated using Eq. (2). Thereafter, index values above average were categorized as High Risk Perception (1), and below as Low Risk Perception (0).

$C l=\left(W_{1}+W_{2}+W_{3}+\ldots . . W_{n}\right) / n$

Eq. 1

Risk Perception Index (RPI) $=\sum_{i=1}^{10} W i / n$

Eq. 2 
Table 1. Indicators selected for assessment of perceived risk.

\begin{tabular}{|c|c|c|}
\hline $\begin{array}{l}\text { Sr. } \\
\text { No }\end{array}$ & Flood Risk Perception Indicators & $\begin{array}{l}\text { Empirical Evidences by } \\
\text { Studies (see referred } \\
\text { papers) }\end{array}$ \\
\hline \multirow[t]{2}{*}{1} & Perceived likelihood of flood: & \\
\hline & $\begin{array}{l}\text { Question: What do you think is the chance for future flood } \\
\text { occurrence? }\end{array}$ & {$[4,5,32,36,46,49,50]$} \\
\hline \multirow[t]{2}{*}{2} & Perceived dread/fear: & \\
\hline & Question: How much are you afraid of floods? & {$[32,46,49,50]$} \\
\hline \multirow[t]{2}{*}{3} & Perceived threat to life: & \\
\hline & $\begin{array}{l}\text { Question: What do you think are the chances of loss of lives } \\
\text { in floods? }\end{array}$ & {$[32,50]$} \\
\hline 4 & $\begin{array}{l}\text { Perceived likelihood of flood damages: } \\
\text { Question: What is the likelihood of future damages by floods? }\end{array}$ & {$[4,32,36,43,46,49]$} \\
\hline \multirow[t]{2}{*}{5} & Perceived ability to cope: & \\
\hline & $\begin{array}{l}\text { Question: What do you think is your capability to cope with } \\
\text { future flood? }\end{array}$ & {$[32,49]$} \\
\hline \multirow[t]{2}{*}{6} & Supplies interruption: & \\
\hline & $\begin{array}{l}\text { Question: What are the chances of supplies interruption } \\
\text { during floods? }\end{array}$ & {$[17,46]$} \\
\hline \multirow[t]{2}{*}{7} & Adapting lifestyles: & \\
\hline & $\begin{array}{l}\text { Question: What are the chances that flood will change your } \\
\text { lifestyles? }\end{array}$ & {$[32,49]$} \\
\hline \multirow[t]{2}{*}{8} & Altering relationships: & \\
\hline & $\begin{array}{l}\text { Question: What are the chances that flood will change your } \\
\text { relationships with friends and neighbours? }\end{array}$ & {$[17,52]$} \\
\hline \multirow[t]{2}{*}{9} & Knowledge about Emergency Protocols: & \\
\hline & $\begin{array}{l}\text { Question: What is the level of understanding emergency } \\
\text { protocols? }\end{array}$ & {$[5,32]$} \\
\hline \multirow[t]{2}{*}{10} & Trust in government policies: & \\
\hline & $\begin{array}{l}\text { Question: How much do you agree with govt. polices for } \\
\text { disaster risk reduction and climate change adaptation? }\end{array}$ & {$[5,17]$} \\
\hline
\end{tabular}

\subsection{Data analysis}

In this study, risk perception is computed as a discrete variable, i.e. either its high perceived risk or low perceived risk. For high perceived risk, this study uses a dummy of 1 , otherwise 0 . Since the dependent variable is in the form of 1 or 0 , logit model, i.e. adjusted regression, was used $[75,76]$. Logistic regression is a standard econometric estimation technique used when the dependent variable is binary, alternative or dichotomous, rather than continuous. Logit analysis is based on the prediction of the probability of an event that may or may not occur. Thus, the calculated probability of risk perception can be equal to 1 or 0 . Logistic regression models are further characterized as ordinary squares regression (OLS) and odds ratio regression. This study applied both methods to affirm the influence of independent variables (socioeconomic factors) on the dependant variable (high perceived risk) to identify the determinants of risk perception.

Socioeconomic indicators that regressed with flood risk perception were household size, age, educational level, employment status, occupation type, house ownership, number of persons employed in the household, monthly income, sources of income, location of house and past experiences (Table 2). The occupation type was classified based on level of economic vulnerability (1 = unemployed, 2 = daily wage earner, 3 = agriculture related worker, 4 = trade and commerce related, $5=$ government employee). Another factor, location of house from hazard proximity, was 
classified based on distance and height ( 1 = between levees and riverbank, 2 = within floodplain, $3=$ Upland), and educational level was classified into five categories ( $1=$ illiterate, 2 = primary schooled, $3=$ middle schooled, $4=$ high schooled, $5=$ college/university graduate). Moreover, due to very low number of female respondents (only $3 \%$ ), gender indicator was dropped from the analysis.

Table 2. Variables used in Model.

\begin{tabular}{|c|c|c|c|c|c|c|}
\hline Indicators & Classification & $\begin{array}{l}\text { Descriptive } \\
\text { Statistics }\end{array}$ & $\begin{array}{l}\text { Dhok Ratta, } \\
\text { Rawalpindi }\end{array}$ & $\begin{array}{l}\text { Hajipura, } \\
\text { Sialkot }\end{array}$ & $\begin{array}{l}\text { Khangarh } \\
\text { City, } \\
\text { Muzaffargarh }\end{array}$ & $\begin{array}{l}\text { Combined } \\
\text { (All Communities) }\end{array}$ \\
\hline \multirow[t]{2}{*}{ Household Size } & Numeric & Mean & 5.40 & 5.64 & 5.46 & 5.50 \\
\hline & & Std. Dev & 1.68 & 2.04 & 2.64 & 2.150 \\
\hline \multirow[t]{2}{*}{ Age } & Numeric & Mean & 37.49 & 39.31 & 39.11 & 38.64 \\
\hline & & Std. Dev & 11.56 & 15.15 & 14.61 & 13.132 \\
\hline \multirow{2}{*}{$\begin{array}{l}\text { Employment } \\
\text { status of } \\
\text { Household head }\end{array}$} & $1=Y e s$ & Mean & 0.87 & 0.80 & 0.90 & 0.86 \\
\hline & $0=\mathrm{No}$ & Std. Dev & 0.337 & 0.403 & 0.302 & 0.351 \\
\hline \multirow[t]{2}{*}{ House Ownership } & $1=$ Yes & Mean & 0.54 & 0.89 & 0.97 & 0.80 \\
\hline & $0=\mathrm{No}$ & Std. Dev & 0.50 & 0.38 & 0.16 & 0.351 \\
\hline \multirow{2}{*}{$\begin{array}{l}\text { Number of } \\
\text { persons } \\
\text { employed in the } \\
\text { household }\end{array}$} & Numeric & Mean & 1.27 & 1.44 & 1.57 & 1.43 \\
\hline & & Std. Dev & 0.479 & 0.810 & 1.199 & 0.884 \\
\hline \multirow{2}{*}{$\begin{array}{l}\text { Monthly income } \\
\text { (in PKR) }\end{array}$} & Numeric & Mean & 23528 & 42057 & 22992 & 29526 \\
\hline & & Std. Dev & 9613 & 39979 & 163341 & 26931 \\
\hline \multirow{2}{*}{$\begin{array}{l}\text { Sources of } \\
\text { Income }\end{array}$} & Numeric & Mean & 1.30 & 1.74 & 1.54 & 1.53 \\
\hline & & Std. Dev & 0.462 & 0.695 & 0.652 & 0.635 \\
\hline \multirow[t]{2}{*}{ Past experiences } & $1=$ Yes & Mean & 0.67 & 0.91 & 0.77 & 0.79 \\
\hline & $0=\mathrm{No}$ & Std. Dev & 0.473 & 0.282 & 0.423 & 0.411 \\
\hline
\end{tabular}

Source: Field Survey, 2015

\section{Results and discussion}

\subsection{Flood hazard exposure in selected communities}

Communities in the selected urban areas experienced varying flood hazard and exposure as the main source of flooding was different in each region. Nullah ${ }^{2}$ Lai passing through the city centre was seen as the flood hazard source in Rawalpindi. Similarly, in Sialkot, Nullah Degh and Nullah Aik were considered flood hazard source in the past. Muzaffargarh and its rural extent have regularly seen riverine flooding, as it lies between Chenab and Indus rivers. Except for Rawalpindi, parts of Sialkot and Muzaffargarh witnessed the devastating super-floods of 2010, which left half of Pakistan paralyzed [67]. In Rawalpindi, the maximum frequency of floods reported by any household was six, whereas the highest were reported as seven in both Sialkot and Muzaffargarh areas. The average height of floodwater witnessed by the communities in Rawalpindi, Sialkot and Muzaffargarh areas was around $0.7 \mathrm{~m}, 1 \mathrm{~m}$, and $1.2 \mathrm{~m}$, respectively. These basic flood characteristics indicate that Muzaffargarh faced the highest flood hazard, followed by Sialkot and Rawalpindi.

\subsection{Flood risk perception}

The values of each flood risk perception indicator varied among the case study areas (Table 3). Significant differences were observed in almost all the indicators, except perceived ability to cope and perceived interruption in supplies which showed minimum spatial variability. Regarding the likelihood of a flooding, households in Rawalpindi (mean $=2.33$ ) believed less in the possibility of future occurrence of floods as compared to Sialkot (mean $=3.01$ ) and Muzaffargarh (mean $=3.31$ ). Significant differences $(F=21.444, p$-value $=0.000)$ can be attributed to a smaller number of floods witnessed by the households of Dhok Ratta, Rawalpindi compared to the other two communities. Moreover, a lower score for fear was observed in the same community - households in Rawalpindi

\footnotetext{
${ }^{2}$ Drainage channel fed by seasonal rains.
} 
were less afraid of floods (mean $=2.73$ ), whereas most afraid were the respondents in Muzaffargarh (mean $=4.54$ ). Similarly, regarding the threat to life due to flood, households in Rawalpindi perceived less threat to life (mean $=2.97$ ) in comparison with Sialkot and Muzaffargarh which exhibited the mean values of 4.36 and 4.59 respectively. All three communities had significant variation in both perceived fear $(F=101.831, p$-value $=0.000)$ and perceived threat to life $(F=$ $71.334, p$-value $=0.000$ ). The lowest score in Rawalpindi may be attributed to limited experiences, temporal dissonance and damages during the past flood events, as last major flooding occurred back in 2005.

Table 3. Indicators of flood risk perception.

\begin{tabular}{|c|c|c|c|c|c|c|}
\hline Indicators & $\begin{array}{l}\text { Descriptive } \\
\text { Statistics }\end{array}$ & $\begin{array}{l}\text { Dhok } \\
\text { Ratta, } \\
\text { Rawalpindi }\end{array}$ & $\begin{array}{l}\text { Dhok } \\
\text { Ratta, } \\
\text { Sialkot }\end{array}$ & $\begin{array}{l}\text { Khangarh } \\
\text { City, } \\
\text { Muzaffargarh }\end{array}$ & $\begin{array}{l}\text { ANOVA } \\
\text { (F-test) }\end{array}$ & $\begin{array}{l}\text { Combined } \\
\text { (All Communities) }\end{array}$ \\
\hline \multirow{2}{*}{$\begin{array}{l}\text { Perceived likelihood of } \\
\text { flood }\end{array}$} & Mean & 2.23 & 3.01 & 3.31 & $21.444^{* * *}$ & 2.85 \\
\hline & Std. Dev & 0.837 & 0.893 & 1.257 & & 1.108 \\
\hline \multirow[t]{2}{*}{ Perceived dread/fear } & Mean & 2.73 & 4.09 & 4.54 & $101.831 * * *$ & 3.79 \\
\hline & Std. Dev & 0.916 & 0.583 & 0.811 & & 1.097 \\
\hline \multirow{2}{*}{ Perceived threat to life } & Mean & 2.97 & 4.36 & 4.59 & $71.334 * * *$ & 3.97 \\
\hline & Std. Dev & 1.116 & 0.781 & 0.625 & & 1.119 \\
\hline \multirow{2}{*}{$\begin{array}{l}\text { Perceived likelihood of } \\
\text { flood damages }\end{array}$} & Mean & 2.74 & 3.59 & 4.16 & $35.670 * * *$ & 3.50 \\
\hline & Std. Dev & 1.099 & 0.909 & 0.973 & & 1.150 \\
\hline \multirow{2}{*}{$\begin{array}{l}\text { Perceived ability to } \\
\text { cope }\end{array}$} & Mean & 2.77 & 2.60 & 2.59 & 1.288 & 2.65 \\
\hline & Std. Dev & 0.705 & 0.668 & 0.893 & & 0.763 \\
\hline \multirow{2}{*}{ Supplies interruption } & Mean & 3.06 & 3.29 & 3.36 & 1.872 & 3.23 \\
\hline & Std. Dev & 0.899 & 0.801 & 1.143 & & 0.962 \\
\hline \multirow{2}{*}{$\begin{array}{l}\text { Readiness to adapt } \\
\text { lifestyles }\end{array}$} & Mean & 2.20 & 2.93 & 2.74 & $13.211 * * *$ & 2.62 \\
\hline & Std. Dev & 1.001 & 0.729 & 0.863 & & 0.921 \\
\hline \multirow{2}{*}{$\begin{array}{l}\text { Readiness to alter } \\
\text { relationships }\end{array}$} & Mean & 2.47 & 3.70 & 4.15 & $55.235 * * *$ & 3.44 \\
\hline & Std. Dev & 1.073 & 0.805 & 1.026 & & 1.201 \\
\hline \multirow{2}{*}{$\begin{array}{l}\text { Knowledge about } \\
\text { mitigation actions }\end{array}$} & Mean & 2.11 & 2.44 & 2.11 & $4.440 * *$ & 2.22 \\
\hline & Std. Dev & 0.578 & 0.581 & 1.015 & & 0.766 \\
\hline \multirow{3}{*}{$\begin{array}{l}\text { Trust in government } \\
\text { policies }\end{array}$} & Mean & 2.33 & 1.80 & 1.64 & $14.305^{* * *}$ & 1.92 \\
\hline & Std. Dev & 0.829 & 0.672 & 0.869 & & 0.844 \\
\hline & Min & 0.18 & 0.20 & 0.24 & $69.498 * * *$ & 0.18 \\
\hline \multirow{3}{*}{$\begin{array}{l}\text { Risk Perception Index } \\
\text { (Standardized) }\end{array}$} & Max & 0.54 & 0.58 & 0.64 & & 0.64 \\
\hline & Mean & 0.356 & 0.473 & 0.515 & & 0.449 \\
\hline & Std. Dev & 0.093 & 0.063 & 0.087 & & 0.106 \\
\hline \multirow{2}{*}{$\begin{array}{l}\text { Dichotomous Risk } \\
\text { Perception } \\
\text { (0= Low Risk, } 1= \\
\text { Perceived Risk) }\end{array}$} & Mean & 0.21 & 0.77 & 0.79 & $42.844^{* * *}$ & 0.59 \\
\hline & Std. Dev & 0.413 & 0.423 & 0.413 & & 0.493 \\
\hline
\end{tabular}

*, Significant at $10 \%,{ }^{* *}$ Significant at $5 \%, * * *$ Significant at $1 \%$.

For peoples' perception concerning the ability to deal with floods, no significant difference was observed among the three communities. Rawalpindi had the highest score of 2.74, while Sialkot and Muzaffargarh had almost similar scores of 2.60 and 2.59 respectively. Similarly, perception of supplies interruption (e.g., food, water supply, medicine etc.) was also somewhat consistent among the case study areas, where residents of Rawalpindi perceived less threat to interruption of supplies due to flood followed by Sialkot and Muzaffargarh (Fig. 2). Residents of the flood-prone area of Sialkot and Muzaffargarh also believed that flood may affect their relationships with friends and acquaintances. However, the score for this indicator was quite low for Rawalpindi (2.47), as compared to Sialkot (3.70) and Muzaffargarh (4.15). The possible reason could be the relatively smaller size of Muzaffargarh city where people are more connected and are in good terms with each other, and thus believe that floods could affect their relationships. All three communities had significant variation in both perceived change in lifestyle $(F=13.211, p$-value $=0.000)$ and altering relationship $(F=55.235, p$-value $=0.000)$. Households' knowledge of mitigation actions and emergency procedures was almost similar in Rawalpindi and Muzaffargarh area (i.e., 2.11), but 
slightly higher in Sialkot (2.44). Overall, the scores were quite low indicating that households have limited knowledge of mitigation and emergency procedures (Table 3). Trust in government authorities regarding policies on DRR got the lowest overall scores compared to other indicators. Muzaffargarh community had serious mistrust in government policies (mean $=1.64$ ), followed by Sialkot (mean $=1.8$ ) and least in Rawalpindi (mean $=2.33$ ). This fluctuation in the scores may be associated with the flood occurrences and performance of government in rescue, relief and flood mitigation initiatives.

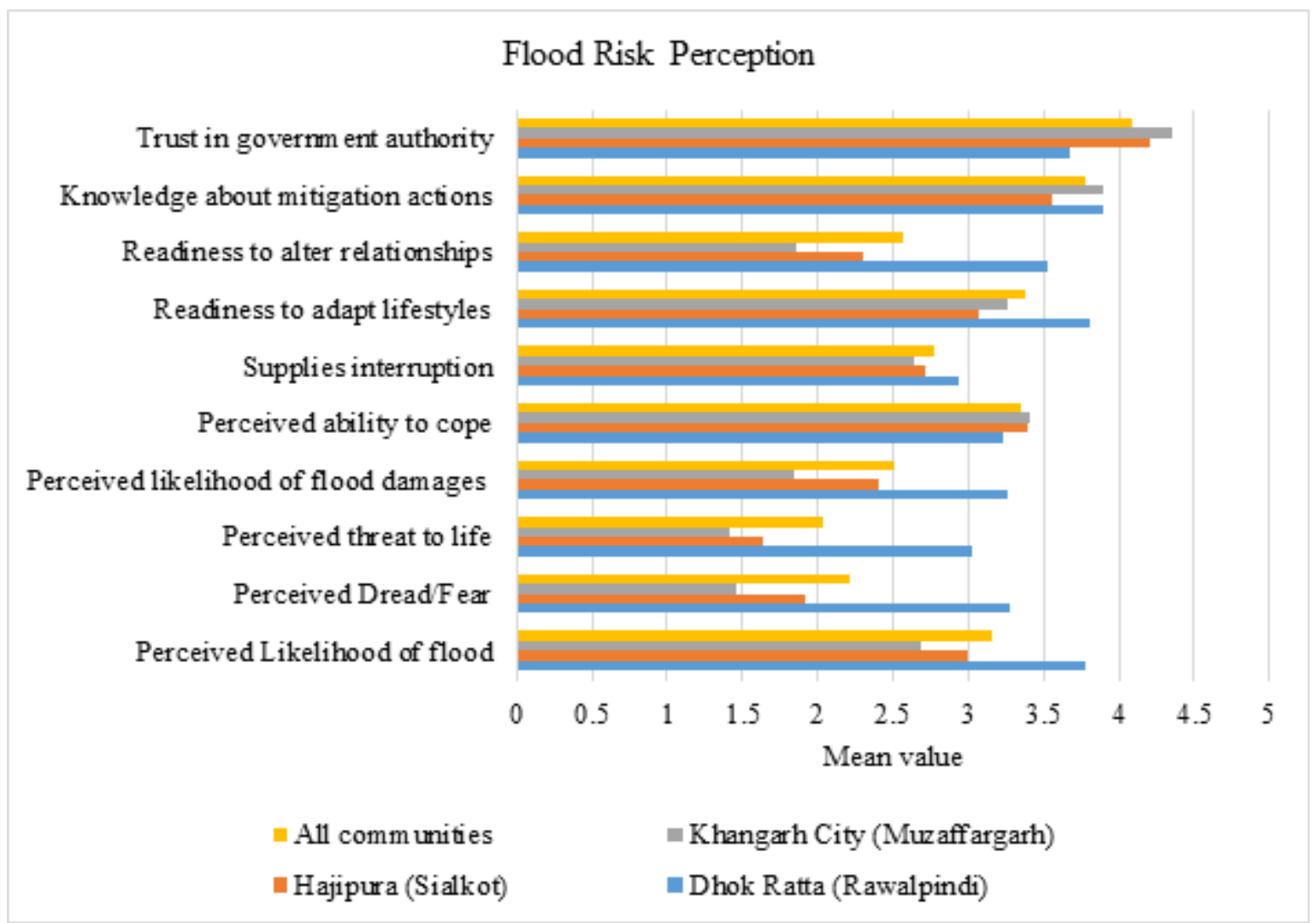

Fig. 2. Mean values of Flood Risk Indicators.

In terms of overall flood risk perception, significant variation was found among the three communities $(F=69.498$, $p$-value $=0.000)$. Risk perception was lowest in Rawalpindi followed by Sialkot and Muzaffargarh. The overall risk perception was generally low, which is alarming as all three communities were in a high flood risk area. The results indicate that threat to life and fear were poorly perceived, compared to other indicators. This can be attributed to prevalent public mindset that future floods can damage others but not them. This finding is also consistent with the work of other researchers who found that people living in flood-prone areas generally perceive the risk as low [36]. This could be one of the possible reasons that they are living in a (hazardous) floodplain area in the first place. However, this low perception can be dangerous as it weakens flood risk reduction initiatives [63], and also endangers the flood-prone communities.

\subsection{Psychosocial factors of flood risk}

\subsubsection{Goodness-of-fit test}

Firstly, to check the limitation of logistic model and obtain robust estimates, correlation matrix was constructed. The results of this matrix showed very weak correlation among different determinants 
of risk perception ${ }^{3}$, which confirms the absence of multicollinearity among the variables ${ }^{4}$. To further check whether the logistic model fits, Hosmer-Lemeshow test and receiver operating curve (ROC) method were also applied ${ }^{5}$. The result of Hosmer-Lemshow test indicated a high value which makes this model a good fit $[75,76]$ (Table 4). In the ROC method, the area under the curve illustrates the likelihood that the proposed model will determine high probability of the factors influencing high perceived risk. A model with no discrimination will have no area under the curve, which would then produce a straight line. The ROC Curve for the model had a value of 0.762 , which according to Hosmer and Lemeshow (2000) [77], falls into the category of excellent discrimination and shows the overall goodness-of-fit of the model (Fig. 3).

Table 4. Variables regressed against Risk Perception.

\begin{tabular}{|c|c|c|c|c|c|c|c|c|}
\hline \multirow[t]{2}{*}{$\begin{array}{l}\text { Independent } \\
\text { Variables }\end{array}$} & \multicolumn{2}{|c|}{$\begin{array}{l}\text { Model } 1 \\
\text { (Dhok Ratta, Rawalpindi) }\end{array}$} & \multicolumn{2}{|c|}{$\begin{array}{l}\text { Model } 2 \\
\text { (Hajipura, Sialkot) }\end{array}$} & \multicolumn{2}{|c|}{$\begin{array}{l}\text { Model } 3 \\
\text { (Khangarh City, } \\
\text { Muzaffargarh) }\end{array}$} & \multicolumn{2}{|c|}{$\begin{array}{l}\text { Model } 4 \\
\text { (All communities) }\end{array}$} \\
\hline & OLS & Odds Ratio & OLS & $\begin{array}{l}\text { Odds } \\
\text { Ratio }\end{array}$ & OLS & $\begin{array}{l}\text { Odds } \\
\text { Ratio }\end{array}$ & OLS & $\begin{array}{l}\text { Odds } \\
\text { Ratio }\end{array}$ \\
\hline $\begin{array}{l}\text { Household Size } \\
\text { (HHSize) }\end{array}$ & $\begin{array}{l}-1.252 * * \\
(0.613)\end{array}$ & $\begin{array}{l}0.285 * * \\
(0.175)\end{array}$ & $\begin{array}{l}0.4233 \\
(0.278) \\
\end{array}$ & $\begin{array}{l}1.528 \\
(0.424) \\
\end{array}$ & $\begin{array}{l}0.838 * * * \\
(0.316)\end{array}$ & $\begin{array}{l}2.313 * * * \\
(0.731)\end{array}$ & $\begin{array}{l}0.147 \\
(0.092)\end{array}$ & $\begin{array}{l}1.159 \\
(0.107)\end{array}$ \\
\hline Age & $\begin{array}{l}0.032 \\
(0.051)\end{array}$ & $\begin{array}{l}1.032 \\
(0.052)\end{array}$ & $\begin{array}{l}0.034 \\
(0.031)\end{array}$ & $\begin{array}{l}1.035 \\
(0.033)\end{array}$ & $\begin{array}{l}-0.031 \\
0.034\end{array}$ & $\begin{array}{l}0.969 \\
(0.033)\end{array}$ & $\begin{array}{l}-0.002 \\
(0.014)\end{array}$ & $\begin{array}{l}0.997 \\
(0.014)\end{array}$ \\
\hline $\begin{array}{l}\text { Education } \\
\text { (Edu) }\end{array}$ & $\begin{array}{l}1.246 * \\
(0.698)\end{array}$ & $\begin{array}{l}3.478 * \\
(2.428) \\
\end{array}$ & $\begin{array}{l}0.372 \\
(0.314)\end{array}$ & $\begin{array}{l}1.451 \\
(0.456)\end{array}$ & $\begin{array}{l}-0.262 \\
0.344\end{array}$ & $\begin{array}{l}0.769 \\
(0.265)\end{array}$ & $\begin{array}{l}-0.122 \\
(0.131)\end{array}$ & $\begin{array}{l}0.884 \\
(0.115)\end{array}$ \\
\hline $\begin{array}{l}\text { Household Head } \\
\text { Employed } \\
\text { (HHEmp) }\end{array}$ & $\begin{array}{l}9.763 * * \\
(3.876)\end{array}$ & $\begin{array}{l}17384.22 * * \\
67383.1\end{array}$ & $\begin{array}{l}1.399 \\
(1.213)\end{array}$ & $\begin{array}{l}4.053 \\
(4.917)\end{array}$ & $\begin{array}{l}-1.022 \\
1.817\end{array}$ & $\begin{array}{l}0.359 \\
(0.653)\end{array}$ & $\begin{array}{l}0.492 \\
(0.563)\end{array}$ & $\begin{array}{l}1.636 \\
(0.921)\end{array}$ \\
\hline $\begin{array}{l}\text { Occupation } \\
\text { (Occu) }\end{array}$ & $\begin{array}{l}-3.020 * * \\
(1.166) \\
\end{array}$ & $\begin{array}{l}0.048 * * \\
(0.056) \\
\end{array}$ & $\begin{array}{l}-0.499 \\
(0.374) \\
\end{array}$ & $\begin{array}{l}0.607 \\
(0.227) \\
\end{array}$ & $\begin{array}{l}0.210 \\
0.445 \\
\end{array}$ & $\begin{array}{l}1.23 \\
(0.549) \\
\end{array}$ & $\begin{array}{l}-0.136 \\
(0.155) \\
\end{array}$ & $\begin{array}{l}0.872 \\
(0.135) \\
\end{array}$ \\
\hline $\begin{array}{l}\text { House Ownership } \\
\text { (HOwn) }\end{array}$ & $\begin{array}{l}10.381 * * * \\
(3.781)\end{array}$ & $\begin{array}{l}32269.23^{* * *} \\
122033.9\end{array}$ & $\begin{array}{l}-1.923 \\
(1.519)\end{array}$ & $\begin{array}{l}0.146 \\
(0.221)\end{array}$ & Omitted & Omitted & $\begin{array}{l}2.164 * * * \\
(0.452)\end{array}$ & $\begin{array}{l}8.710 * * * \\
(3.941)\end{array}$ \\
\hline $\begin{array}{l}\text { Number of Earners } \\
\text { (NoEmpl) }\end{array}$ & $\begin{array}{l}-0.085 \\
(1.112) \\
\end{array}$ & $\begin{array}{l}0.917 \\
(1.020) \\
\end{array}$ & $\begin{array}{l}-0.716 \\
0.766) \\
\end{array}$ & $\begin{array}{l}0.488 \\
(0.374)\end{array}$ & $\begin{array}{l}-0.614 \\
0.709 \\
\end{array}$ & $\begin{array}{l}0.541 \\
(0.383)\end{array}$ & $\begin{array}{l}-0.288 \\
(0.234)\end{array}$ & $\begin{array}{l}0.749 \\
(0.175)\end{array}$ \\
\hline $\begin{array}{l}\text { Income } \\
\text { (Inc) }\end{array}$ & $\begin{array}{l}-0.000 \\
(0.000)\end{array}$ & $\begin{array}{l}0.999 \\
(0.000)\end{array}$ & $\begin{array}{l}0.000 \\
(0.000)\end{array}$ & $\begin{array}{l}1.000 \\
(0.000)\end{array}$ & $\begin{array}{l}-0.000 \\
0.000\end{array}$ & $\begin{array}{l}0.999 \\
(0.000)\end{array}$ & $\begin{array}{l}0.000 \\
0.000 \\
\end{array}$ & $\begin{array}{l}1.000 \\
(0.000)\end{array}$ \\
\hline $\begin{array}{l}\text { Sources of Income } \\
\text { (Source) }\end{array}$ & $\begin{array}{l}-0.285 \\
(1.173) \\
\end{array}$ & $\begin{array}{l}0.751 \\
(0.882) \\
\end{array}$ & $\begin{array}{l}-0.987 \\
(0.682) \\
\end{array}$ & $\begin{array}{l}0.372 \\
(0.253) \\
\end{array}$ & $\begin{array}{l}0.415 \\
0.663 \\
\end{array}$ & $\begin{array}{l}1.515 \\
(1.005) \\
\end{array}$ & $\begin{array}{l}0.064 \\
(0.307) \\
\end{array}$ & $\begin{array}{l}1.066 \\
(0.327) \\
\end{array}$ \\
\hline $\begin{array}{l}\text { Location of House } \\
\text { (Loca) }\end{array}$ & $\begin{array}{l}2.305^{*} \\
(1.252)\end{array}$ & $\begin{array}{l}10.031^{*} \\
12.567 \\
\end{array}$ & $\begin{array}{l}-1.016 \\
(0.679) \\
\end{array}$ & $\begin{array}{l}0.361 \\
(0.245)\end{array}$ & $\begin{array}{l}-0.414 \\
0.503 \\
\end{array}$ & $\begin{array}{l}0.660 \\
(0.332)\end{array}$ & $\begin{array}{l}-0.230 \\
(0.232) \\
\end{array}$ & $\begin{array}{l}0.794 \\
(0.184) \\
\end{array}$ \\
\hline $\begin{array}{l}\text { Past Experiences } \\
\text { (Past) }\end{array}$ & $\begin{array}{l}6.561 * * \\
(2.709) \\
\end{array}$ & $\begin{array}{l}707.329 * * \\
1916.831 \\
\end{array}$ & $\begin{array}{l}0.1299 \\
(1.254) \\
\end{array}$ & $\begin{array}{l}1.138 \\
(1.428) \\
\end{array}$ & $\begin{array}{l}0.556 \\
1.024 \\
\end{array}$ & $\begin{array}{l}1.744 \\
(1.787) \\
\end{array}$ & $\begin{array}{l}0.889 * * \\
(0.414)\end{array}$ & $\begin{array}{l}2.433^{* *} \\
(1.007) \\
\end{array}$ \\
\hline _cons & $\begin{array}{l}-13.335^{* *} \\
(6.101)\end{array}$ & $\begin{array}{l}0.000 * * \\
0.000 \\
\end{array}$ & $\begin{array}{l}4.045 \\
(2.809) \\
\end{array}$ & $\begin{array}{l}57.162 \\
(160.602) \\
\end{array}$ & $\begin{array}{l}1.606 \\
2.625 \\
\end{array}$ & $\begin{array}{l}4.984 \\
(13.086)\end{array}$ & $\begin{array}{l}-1.714 \\
(1.208)\end{array}$ & $\begin{array}{l}0.180 \\
(0.217) \\
\end{array}$ \\
\hline $\begin{array}{l}\text { Hosmer- } \\
\text { Lemeshow test }\end{array}$ & - & 4.06 & - & 6.65 & - & 5.15 & - & 10.29 \\
\hline Pseudo $\mathbf{R}^{2}$ & 0.5438 & & 0.1710 & & 0.3029 & & 0.1541 & \\
\hline
\end{tabular}

Standard errors are in parenthesis.

$*$, Significant at $10 \%,{ }^{* *}$ Significant at $5 \%, * * *$ Significant at $1 \%$.

\footnotetext{
${ }^{3}$ Due to brevity purposes, results of correlation matrix are not shown.

${ }^{4}$ The study checked the multicollinearity with variance inflation factor (VIF) test. The results of VIF test was below than 10, which predicts absence of multicollinearity.

${ }^{5}$ The ROC was conducted on full sample of study.
} 


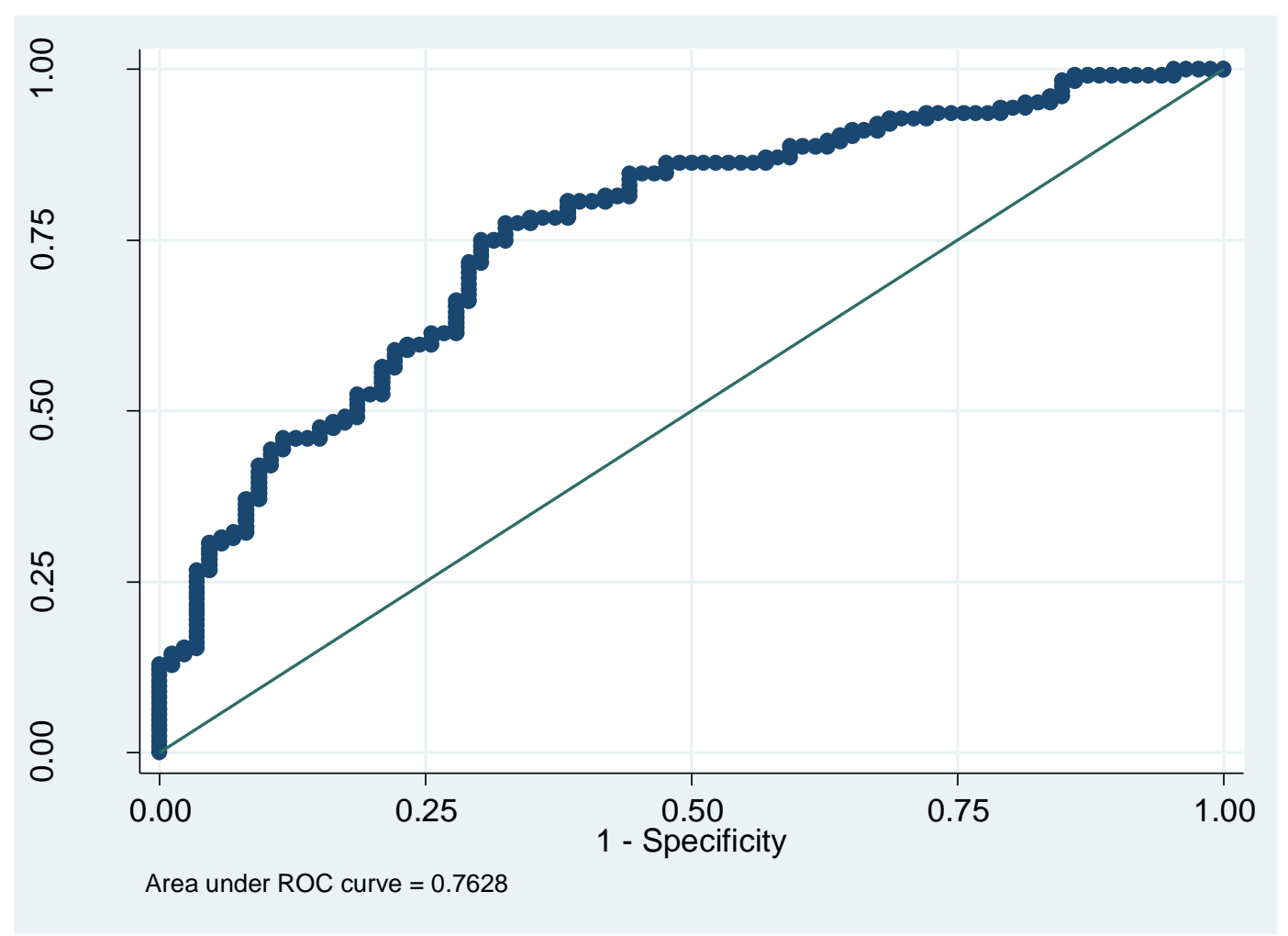

Fig. 3. Receiver operating curve for Combined Model.

\subsubsection{Results of logistic regression models}

Four models were developed to explain the potential socioeconomic factors influencing flood risk perception. Both Ordinary Least Squares (OLS) and Odds-ratios regression were performed for counter-checking each model (Table 4). Models 1, 2 and 3 were developed exclusively for Dhok Ratta (Rawalpindi), Hajipura (Sialkot) and Khangarh city (Muzaffargarh) respectively, whereas model 4 was developed for all three communities collectively. In Model 2 for Hajipura, none of the selected indicators were able to assess impact of factors on flood risk perception.

In Rawalpindi, a negative and significant influence of household size on flood risk perception was observed indicating that a larger household size perceived low risk. This perception maybe influenced by the fact that a large number of household members would help each other during a flood event, and possibly assist recovering from flood impacts. On the contrary, a positive and significant relationship was found between household size and risk perception in Muzaffargarh area. This can be attributed to higher exposure of households with past flood events. However, in overall urban communities, it was found that the household size did not influence flood risk perception.

Education on the other hand significantly and positively influenced risk perception in Rawalpindi. The finding implies that individuals with higher educational qualifications would potentially perceive high flood risk in a high flood risk area [60]. However, this was only observed in Rawalpindi and not in the models of other two communities. Employment status of household head and occupation was also found to influence risk perception, in Rawalpindi only. An employed household head would perceive high flood risk possibly due to frequent social and communal interactions.

House ownership was also found to influence risk perception. In Model 3, the house ownership was omitted from the model because of inconsistency. However, it was found true for combined model of all communities and Rawalpindi community. This finding agrees with similar studies, where researchers have observed varying affects $[53,60]$. Location of the house from hazard source was 
found to influence risk perception, but only in Rawalpindi. Households living upland were perceiving flood risk more than households living in the floodplain. This implies that people who have settled in floodplains have poor risk perception believing that flood would not affect them. A study by Botzen et al. (2009) also found that people unprotected by dikes/levees were underestimating the flood risk [36]. However, this factor was not found to influence flood risk perception in the models of other two communities.

Past experiences were found to significantly affect flood risk perception in the combined model. However, it was only found true for Rawalpindi where the households that experienced floods in the past were perceiving high risk. It is important to remember that the people in Rawalpindi experienced flash flooding way back in 2005 , as compared to other case study areas where households experienced flooding recently in 2010. Since then (2005), in Rawalpindi, only a few deaths have been attributed to drowning in rapid flows of drainage in Nullah Lai. This might have affected past experiences and time-distance which may have distorted the community's flood risk perception. This study adds support to work of other researches, which have termed past experiences as an integral factor affecting flood risk perception $[4,22,23,27,29,36,53,60]$. It also implies that people who have experienced floods are more ready to accept precautionary measures and undertake protective actions against future threats.

Age, income, number of earners and sources of income did not influence flood risk perception in all four models. Age was not found to influence flood risk perception, aligning with previous studies $[51,53,57,60]$. Income also did not influence flood risk perception in this study, which is consistent with similar studies conducted in the past $[4,32,36,60]$. It can therefore be inferred that risk perception is not affected by the age or economic status of the household members.

Risk perception is a complex psychological phenomenon, which can sometimes be influenced by numerous unexplainable, unquantifiable and unaccountable factors $[4,10,17,31]$. Although the findings suggest that the factors influencing risk perception vary spatially among the three urban flood prone communities, the conclusions, however must be drawn with caution. The adopted methodology supports extant literature on the psychosocial aspects of flood risk, especially past experiences and hazard proximity/geophysical vulnerability [51,53]. The results imply that risk communication strategies must essentially be targeted to households who have not previously experienced floods and those which are residing near hazard sources.

\section{Conclusion}

A good understanding of flood risk would influence community's willingness to adopt precautionary measures. Therefore, it is critical that the public must understand flood risk to accept and support DRR and climate change policies. Due to the multidimensional impacts of flood risk, a multidisciplinary approach must be used to integrate all components of risks, vulnerability and behavioural assessments. Understanding the dynamics of flood risk perception can also help in priority one of Sendai Framework for DRR, i.e., understanding disaster risk.

This study attempted to comprehend the psychosocial aspects of multifaceted flood risk. Few studies have explored flood risk perception in urban communities from cities of different population sizes. This study found that socioeconomic determinants influencing flood risk perception were not consistent in the three selected communities, hence the spatial variance. In addition to understanding flood risk perception, the study confirms importance of past experiences and hazard proximity in affecting the perceived risk. This research emphasizes that these determinants and their variance must be kept in mind by the disaster risk management authorities, whenever identifying potential target audience to communicate risks. This study also provides insights and implications for policy makers, disaster managers and urban planners to undertake a pragmatic approach in 
developing targeted risk communication and flood risk reduction strategies, so that it may turn into protective actions on ground $[1,21,32,36]$.

This study, of course, must acknowledge its limitations. Firstly, majority of respondents were men, which should not be generalized for other genders. Quantifying risk perception is often complicated as respondent's behaviours, judgements and consequent protective actions cannot be measured accurately through some predetermined indicators, as many unforeseen factors are at play. A plethora of theories and frameworks have been developed to explain risk perception, all of which could not be entertained in this study. Further research is required to examine influence of local institutions and sociocultural norms on flood risk perception. A better understanding of flood hazard type with risk perception is also required, especially to differentiate between riverine and surface flooding. It is also advocated to study gendered influences on flood risk perceptions in the future. The relationship and connection between risk perception and risk communication also need to be examined empirically. Keeping in view these challenges, understanding the psychosocial aspect of risk perception can be improved, so that it can be made part of community resilience and vulnerability/risk assessment for both climate change adaptation and disaster risk science.

\section{References}

[1] S. Birkholz, M. Muro, P. Jeffrey, H.M.M. Smith, Rethinking the relationship between flood risk perception and flood management, Sci. Total Environ., 478 (2014), pp. 12-20,

10.1016/j.scitotenv.2014.01.061

[2] S.S. Ainuddin, J. Kumar Routray, S.S. Ainuddin, People's risk perception in earthquake prone Quetta city of Baluchistan, Int. J. Disaster Risk Reduct., 7 (2014), pp. 165-175, 10.1016/j.ijdrr.2013.10.006

[3] P. Slovic, H. Kunreuther, G. White, Decision processes, rationality and adjustment to natural hazards, P. Slovic (Ed.), Percept. Risk, Routledge, London (2000), pp. 39-69

[4] K.A. Sullivan-Wiley, A.G. Short Gianotti, Risk perception in a multi-hazard environment, World Dev., 97 (2017), pp. 138-152, 10.1016/j.worlddev.2017.04.002

[5] M. Diakakis, G. Priskos, M. Skordoulis, Public perception of flood risk in flash flood prone areas of Eastern Mediterranean: the case of Attica Region in Greece, Int. J. Disaster Risk Reduct., 28 (2018), pp. 404-413, 10.1016/j.ijdrr.2018.03.018

[6] S. Doocy, A. Daniels, S. Murray, T.D. Kirsch, The human impact of floods: a historical review of events 1980-2009 and systematic literature review, PLoS Curr (2013),

10.1371/currents.dis.f4deb457904936b07c09daa98ee8171a

[7] Y. Kinoshita, M. Tanoue, S. Watanabe, Y. Hirabayashi, Quantifying the effect of autonomous adaptation to global river flood projections: application to future flood risk assessments, Environ.

Res. Lett., 13 (2018), Article 014006, 10.1088/1748-9326/aa9401

[8] B. Jongman, H.C. Winsemius, S.A. Fraser, S. Muis, P.J. Ward, Assessment and Adaptation to Climate Change-Related Flood Risks, Oxford University Press (2018),

10.1093/acrefore/9780199389407.013.278

[9] Y. Hirabayashi, R. Mahendran, S. Koirala, L. Konoshima, D. Yamazaki, S. Watanabe, H. Kim, S. Kanae, Global flood risk under climate change, Nat. Clim. Change, 3 (2013), p. 816,

10.1038/nclimate1911

[10] J.C.J.H. Aerts, W.J. Botzen, K.C. Clarke, S.L. Cutter, J.W. Hall, B. Merz, E. Michel-Kerjan, J. Mysiak, S. Surminski, H. Kunreuther, Integrating human behaviour dynamics into flood disaster risk assessment, Nat. Clim. Change, 8 (2018), pp. 193-199, 10.1038/s41558-018-0085-1

[11] B. Wisner, P. Blaikie, T. Cannon, I. Davis, At Risk: Natural Hazards, People's Vulnerability and Disasters, (second ed.), Routledge, London (2004)

[12] I.A. Rana, J.K. Routray, Integrated methodology for flood risk assessment and application in urban communities of Pakistan, Nat. Hazards, 91 (2018), pp. 239-266, 10.1007/s11069-017-3124-8 
[13] I.S.S.C. ICSU, Review of Targets for the Sustainable Development Goals: the Science Perspective, International Council for Science (ICSU), Paris (2015)

http://www.icsu.org/publications/reports-and-reviews/review-of-targets-for-the-sustainabledevelopment-goals-the-science-perspective-2015/SDG-Report.pdf

[14] United Nations, New Urban Agenda, Quito (2017)

http://habitat3.org/wp-content/uploads/NUA-English.pdf

[15] UNDP, United Nations Development Programme, UNDP, Human Development Report 2015

978-92-1-126398-5, Work for Human Development, New York (2015)

[16] I.A. Rana, S.S. Bhatti, S. e Saqib, The spatial and temporal dynamics of infrastructure development disparity - from assessment to analyses, Cities, 63 (2017), pp. 20-32,

10.1016/j.cities.2016.12.020

[17] I.A. Rana, J.K. Routray, Actual vis-à-vis perceived risk of flood prone urban communities in Pakistan, Int. J. Disaster Risk Reduct., 19 (2016), pp. 366-378, 10.1016/j.ijdrr.2016.08.028

[18] R.C. Franklin, J.C. King, P.J. Aitken, P.A. Leggat, "Washed away"-assessing community perceptions of flooding and prevention strategies: a North Queensland example, Nat. Hazards, 73 (2014), pp. 1977-1998, 10.1007/s11069-014-1180-x

[19] W. Kellens, T. Terpstra, P. De Maeyer, Perception and communication of flood risks: a systematic review of empirical research, Risk Anal., 33 (2013), pp. 24-49, 10.1111/j.1539-

6924.2012.01844.x

[20] G. Wachinger, O. Renn, L. Domènech, I. Jakobson, C. Kuhlicke, L. Lemkow, L. Pellizzoni, A. Piriz, D. Saurí, A. Scolobig, A. Steinführer, M. Supramaniam, R. Whittle, C. Bianchizza, T. Coates, B. De Marchi, Risk Perception and Natural Hazards, (2010), Stuttgart http://caphaz-net.org/outcomes-results/CapHaz-Net_WP3_Risk-Perception.pdf

[21] W.G. Peacock, S.D. Brody, W. Highfield, Hurricane risk perceptions among Florida's single family homeowners, Landsc. Urban Plann., 73 (2005), pp. 120-135, 10.1016/j.landurbplan.2004.11.004

[22] M. Siegrist, H. Gutscher, Flooding risks: a comparison of lay people's perceptions and expert's assessments in Switzerland, Risk Anal., 26 (2006), pp. 971-979, 10.1111/j.15396924.2006.00792.x

[23] M. Mills, K. Mutafoglu, V.M. Adams, C. Archibald, J. Bell, J.X. Leon, Perceived and projected flood risk and adaptation in coastal Southeast Queensland, Australia, Climatic Change, 136 (2016), pp. 523-537, 10.1007/s10584-016-1644-y

[24] O. Renn, Risk Governance: Coping with Uncertainty in a Complex World, Earthscan, London (2008)

[25] P. Slovic, Perception of risk, Science, 80 (236) (1987), pp. 280-285, 10.1126/science.3563507

[26] M.K. Lindell, S.N. Hwang, Households' perceived personal risk and responses in a multihazard environment, Risk Anal., 28 (2008), pp. 539-556, 10.1111/j.1539-6924.2008.01032.x

[27] G.F. White, Human Adjustment to Floods - A Geographical Approach to the Flood Problem in the United States, University of Chicago (1945)

[28] N.D. Weinstein, Effects of personal experience on self-protective behavior, Psychol. Bull., 105 (1989), pp. 31-50, 10.1037/0033-2909.105.1.31

[29] I. Burton, R.W. Kates, The perception of natural hazards in resource management, Nat. Resour. J., III (1964), pp. 412-441, http://biblioteca.usac.edu.gt/tesis/08/08_2469_C.pdf [30] C.H. Green, S.M. Tunstall, M.H. Fordham, The risks from flooding: which risks and whose perception?, Disasters, 15 (1991), pp. 227-236, 10.1111/j.1467-7717.1991.tb00456.x

[31] L. Sjöberg, Factors in risk perception, Risk Anal., 20 (2000), pp. 1-11, 10.1111/02724332.00001

[32] M.-C. Ho, D. Shaw, S. Lin, Y.-C. Chiu, How do disaster characteristics influence risk perception?, Risk Anal., 28 (2008), pp. 635-643, 10.1111/j.1539-6924.2008.01040.x 
[33] M.K. Lindell, S. Arlikatti, C.S. Prater, Why people do what they do to protect against earthquake risk: perceptions of hazard adjustment attributes, Risk Anal., 29 (2009), pp. 1072-1088, 10.1111/j.1539-6924.2009.01243.x

[34] P. Slovic, The Perception of Risk, Earthscan, London (2000)

[35] A. Bustillos Ardaya, M. Evers, L. Ribbe, What influences disaster risk perception? Intervention measures, flood and landslide risk perception of the population living in flood risk areas in Rio de Janeiro state, Brazil, Int. J. Disaster Risk Reduct., 25 (2017), pp. 227-237, 10.1016/j.ijdrr.2017.09.006

[36] W.J.W. Botzen, J.C.J.H. Aerts, J.C.J.M. van den Bergh, Dependence of flood risk perceptions on socioeconomic and objective risk factors, Water Resour. Res., 45 (2009), pp. 1-15, 10.1029/2009WR007743

[37] C. Keller, M. Siegrist, H. Gutscher, The role of the affect and availability heuristics in risk communication, Risk Anal., 26 (2006), pp. 631-639, 10.1111/j.1539-6924.2006.00773.x

[38] L. Greening, S.J. Dollinger, G. Pitz, Adolescents' perceived risk and personal experience with natural disasters: an evaluation of cognitive heuristics, Acta Psychol. (Amst)., 91 (1996), pp. 27-38, 10.1016/0001-6918(94)00040-9

[39] Y. Ge, W. Xu, Z.-H. Gu, Y.-C. Zhang, L. Chen, Risk perception and hazard mitigation in the Yangtze River Delta region, China, Nat. Hazards, 56 (2011), pp. 633-648, 10.1007/s11069-010-9579-5

[40] R. Raaijmakers, J. Krywkow, A. van der Veen, Flood risk perceptions and spatial multi-criteria analysis: an exploratory research for hazard mitigation, Nat. Hazards, 46 (2008), pp. 307-322, 10.1007/s11069-007-9189-z

[41] M. Siegrist, H. Gutscher, Natural hazards and motivation for mitigation behavior: people cannot predict the affect evoked by a severe flood Risk Anal., 28 (2008), pp. 771-778, 10.1111/j.1539-6924.2008.01049.x

[42] J.F. Short, The social fabric at risk: toward the social transformation of risk analysis, Am. Socio. Rev., 49 (2006), p. 711, 10.2307/2095526

[43] A.Y. Lo, The role of social norms in climate adaptation: mediating risk perception and flood insurance purchase, Global Environ. Change, 23 (2013), pp. 1249-1257, 10.1016/j.gloenvcha.2013.07.019

[44] J. Brenot, S. Bonnefous, C. Marris, Testing the cultural theory of risk in France, Risk Anal., 18 (1998), pp. 729-739, 10.1111/j.1539-6924.1998.tb01116.x

[45] X. Shen, Flood Risk Perception and Communication within Risk Management in Different Cultural Contexts, Universitat Bonn (2009)

[46] R. Miceli, I. Sotgiu, M. Settanni, Disaster preparedness and perception of flood risk: a study in an alpine valley in Italy, J. Environ. Psychol., 28 (2008), pp. 164-173, 10.1016/j.jenvp.2007.10.006

[47] J. Twigg, The human factor in early warnings: risk perception and appropriate communications, Early Warn. Syst. Nat. Disaster Reduct., Springer Berlin Heidelberg, Berlin, Heidelberg (2003), pp. 19-26, 10.1007/978-3-642-55903-7_4

[48] A.A. Shah, J. Ye, M. Abid, R. Ullah, Determinants of flood risk mitigation strategies at household level: a case of Khyber Pakhtunkhwa (KP) province, Pakistan, Nat. Hazards, 88 (2017), pp. 415-430, 10.1007/s11069-017-2872-9

[49] P. Babcicky, S. Seebauer, The two faces of social capital in private flood mitigation: opposing effects on risk perception, self-efficacy and coping capacity, J. Risk Res., 20 (2017), pp. 1017-1037, 10.1080/13669877.2016.1147489

[50] W. Kellens, R. Zaalberg, T. Neutens, W. Vanneuville, P. De Maeyer, An analysis of the public perception of flood risk on the Belgian Coast, Risk Anal., 31 (2011), pp. 1055-1068, 10.1111/j.15396924.2010.01571.x

[51] E. O'Neill, F. Brereton, H. Shahumyan, J.P. Clinch, The impact of perceived flood exposure on flood-risk perception: the role of distance, Risk Anal., 36 (2016), pp. 2158-2186, 10.1111/risa.12597

[52] I. Armaş, E. Avram, Perception of flood risk in danube delta, Romania, Nat. Hazards, 50 (2009), pp. 269-287, 10.1007/s11069-008-9337-0 
[53] K.F. Gotham, R. Campanella, K. Lauve-Moon, B. Powers, Hazard experience, geophysical vulnerability, and flood risk perceptions in a postdisaster city, the case of new orleans, Risk Anal., 38 (2018), pp. 345-356, 10.1111/risa.12830

[54] S.J. Halvorson, J.P. Hamilton, In the aftermath of the Qa'yamat: the Kashmir earthquake disaster in northern Pakistan, Disasters, 34 (2010), pp. 184-204, 10.1111/j.1467-7717.2009.01124.x [55] M. Ashraf, J.K. Routray, Perception and understanding of drought and coping strategies of farming households in north-west Balochistan, Int. J. Disaster Risk Reduct., 5 (2013), pp. 49-60, 10.1016/j.ijdrr.2013.05.002

[56] Atta-ur-Rahman, A.N. Khan, A.E. Collins, F. Qazi, Causes and extent of environmental impacts of landslide hazard in the Himalayan region: a case study of Murree, Pakistan, Nat. Hazards, 57 (2011), pp. 413-434, 10.1007/s11069-010-9621-7

[57] R. Ullah, G.P. Shivakoti, G. Ali, Factors effecting farmers' risk attitude and risk perceptions: the case of Khyber Pakhtunkhwa, Pakistan, Int. J. Disaster Risk Reduct., 13 (2015), pp. 151-157, 10.1016/j.ijdrr.2015.05.005

[58] S.E. Saqib, M.M. Ahmad, S. Panezai, I.A. Rana, An empirical assessment of farmers' risk attitudes in flood-prone areas of Pakistan, Int. J. Disaster Risk Reduct., 18 (2016), pp. 107-114, 10.1016/j.ijdrr.2016.06.007

[59] M. Abid, J. Schilling, J. Scheffran, F. Zulfiqar, Climate change vulnerability, adaptation and risk perceptions at farm level in Punjab, Pakistan, Sci. Total Environ., 547 (2016), pp. 447-460, 10.1016/j.scitotenv.2015.11.125

[60] S. Qasim, A. Nawaz Khan, R. Prasad Shrestha, M. Qasim, Risk perception of the people in the flood prone Khyber Pukhthunkhwa province of Pakistan, Int. J. Disaster Risk Reduct., 14 (2015), pp. 373-378, 10.1016/j.ijdrr.2015.09.001

[61] S. Fahad, J. Wang, Farmers' risk perception, vulnerability, and adaptation to climate change in rural Pakistan, Land Use Pol., 79 (2018), pp. 301-309, 10.1016/j.landusepol.2018.08.018

[62] G. Wachinger, O. Renn, C. Begg, C. Kuhlicke, The risk perception paradox-implications for governance and communication of natural hazards, Risk Anal., 33 (2013), pp. 1049-1065,

10.1111/j.1539-6924.2012.01942.x

[63] E. Lechowska, What determines flood risk perception? A review of factors of flood risk perception and relations between its basic elements, Nat. Hazards, 94 (2018), pp. 1341-1366, 10.1007/s11069-018-3480-z

[64] EM-CRED, Disaster Country Profiles, (2017), Pakistan, http://www.emdat.be/country_profile/index.html, checked on 2/2/2018

[65] NDMA, National Disaster Management Plan 2012, (2012), Islamabad

[66] A. Jamshed, I.A. Rana, J. Birkmann, O. Nadeem, Changes in vulnerability and response capacities of rural communities after extreme events: case of major floods of 2010 and 2014 in Pakistan, J. Extrem. Events., 4 (2018), p. 1750013, 10.1142/s2345737617500130

[67] K. Solberg, Worst floods in living memory leave Pakistan in paralysis, Lancet, 376 (2010), pp. 1039-1040, 10.1016/s0140-6736(10)61469-9

[68] Government of Pakistan, National Disaster Risk Reduction Policy, (2013), Islamabad

[69] Punjab Bureau of Statistics, Punjab Development Statistics, (2005), Lahore, 2016, http://www.bos.gop.pk/publicationreports

[70] B. Ahmad, M.S. Kaleem, M.J. Butt, Z.H. Dahri, Hydrological modelling and flood hazard mapping of Nullah Lai, Proc. Pakistan Acad. Sci., 47 (2010), pp. 215-226

[71] NDMA, Multi-sector Initial Rapid Assessment PDMA/NDMA/HCT Punjab Floods, (2014), Islamabad, www.ndma.gov.pk/new/Documents/mira_2014.pdf, checked on 1/26/2015

[72] W. Cochran, Sampling Techniques, (third ed.), John Wiley and Sons, New York (1977)

[73] Punjab Bureau of Statistics, Punjab Development Statistics 2014, (2014), Lahore, http://www.bos.gop.pk/publicationreports

[74] J. Birkmann, Measuring vulnerability to promote disaster-resilient societies: conceptual frameworks and definitions, J. Birkmann (Ed.), Meas. Vulnerability to Nat. Hazards Towar. Disaster 
Resilient Soc., United Nations University - Institute for Environment and Human Security (UNU-EHS), Tokyo (2006), pp. 9-54, 10.1111/j.1539-6975.2010.01389.x

[75] W.H. Greene, Econometric Analysis, (sixth ed.), Pearson Prentice Hall, New Jersey (2007)

[76] J.H. Stock, M.W. Watson, Introduction to Econometrics, (second ed.), Pearson Addison Wesley, Boston (2007)

[77] D.W. Hosmer, S. Lemeshow, Applied Logistic Regression, John Wiley \& Sons, Inc., New York (2000)

[78] Punjab Bureau of Statistics, Punjab Development Statistics 2017, Government of Punjab. Pakistan, Lahore (2017) 